\title{
26. CARBON ISOTOPE ANALYSES OF HEAD SPACE METHANE FROM SAMPLES OF LEG 42B, SITES 379, 380, AND 381
}

\author{
E. Faber, M. Schmitt, and W. Stahl, Federal Institute for Geosciences and Natural Resources, \\ P.O. Box 51 0153, 3000 Hannover 51, Germany
}

\begin{abstract}
The composition of head space gas recovered from five partially canned cores taken from Sites 379, 380, and 381 in the Black Sea in May 1975, had been determined by gas chromatography. In addition, $\delta^{13} \mathrm{C}$ values were obtained from the methane fraction of the gas. These $\delta^{13} \mathrm{C}$ values are in the range of -70 to $-55 \%$ (PDB), which is typical for immature gases, and show a slight enrichment in ${ }^{13} \mathrm{C}$ with increasing depth. The upper parts of Site 379 show extreme enrichment of ${ }^{13} \mathrm{C}$ with $\delta^{13} \mathrm{C}$ values as heavy as $-34 \%$. The ${ }^{13} \mathrm{C}$ enriched methane can be related to a higher $\mathrm{CO}_{2} / \mathrm{CH}_{4}$ ratio and may be explained by bacterial oxidation.
\end{abstract}

\section{INTRODUCTION}

During the cruise of D/V Glomar Challenger in the Black Sea (May 1975) five cores were canned at three sites of Leg 42B (Figure 1). Gas analyses and isotope determinations of 44 head space gases have been carried out in order to determine the range of ${ }^{13} \mathrm{C} /{ }^{12} \mathrm{C}$ variations in the head space methane and to find out the maturity of the organic source material.

\section{TECHNIQUES}

All gas chromatographic or isotopic analyses were performed without blending or heating the samples. Total gas composition of the samples was determined on a Packard Becker model 421 gas chromatograph having a 1.7 meters by $1 / 8$ inch silica gel column and both heat capacity and flame ionization detectors. Methane was separated from $50 \mathrm{cc}$ of head space gas on a Perkin Elmer F $30 \mathrm{H}$ gas chromatograph fitted with a 1.8 meters by $1 / 4$ inch Porapak Q column and a heat capacity detector. The methane was converted to $\mathrm{CO}_{2}$ by oxidizing it in an oven filled with copper oxide and heated to $830^{\circ} \mathrm{C}$. The $\mathrm{CO}_{2}$ was then analyzed on a Micromass 903 mass spectrometer to obtain the $\delta^{13} \mathrm{C}$ ratios. Total reproducibility was about $\pm 1^{\circ} / 00(1 \sigma)$ and was determined by repeated analyses of a synthesized head space gas and by 18 duplicate sample analyses.

\section{RESULTS AND DISCUSSION}

Gas chromatographic and isotope data are compiled in Tables 1 and 2. Besides air, the gases consist predominantly of methane and small amounts of carbon dioxide. Ethane/methane and iso-butane/nbutane ratios increase slightly with depth (Figure 2) and show the start of thermocatalytic hydrocarbon at Site 380. At Site 379 the carbon dioxide content of the $\delta^{13} \mathrm{C}$ of the carbon dioxide in the head space gas decrease with increasing depth (Figures 2 and 3 ). This trend is masked by high carbon dioxide concentrations in at least three to four different core sections. These samples give the largest carbon dioxide/methane ratios (Figure 3 ). The anomalies are also related to anomalously high ${ }^{13} \mathrm{C}$ concentrations in the head space methane. The heavy $\delta^{13} \mathrm{C}$ ratios, which are unusual for immature gases, can be observed in the shallow parts of all three cores (Figures 3 and 4). At a depth of about 25 meters the high amounts of carbon dioxide and the high carbon dioxide/methane ratios at Site 379 can be related to high ${ }^{13} \mathrm{C} /{ }^{12} \mathrm{C}$ ratios of the methane from both deep-sea Sites 379 and 380. The small number of samples taken from the land near Site 381 neither confirm nor deny this relationship. However, an extreme $\delta^{13} \mathrm{C}$ value of $-38^{\circ} \%$ has also been measured at a depth of 133 meters at Site 381 . At Site 379, less pronounced $\delta^{13} \mathrm{C}$ maxima are observed at depths of about 130 meters, 380 meters, and 440 meters. One possible explanation for these heavy $\delta^{13} \mathrm{C}$ values may be bacterial oxidation of the methane during a sea-level regression. Lebedew et al. (1969) have shown that bacteria preferentially oxidize light methane and thus leave a relatively heavy residuum. Alternatively, an increase in the ${ }^{13} \mathrm{C}$ concentration of the head space methane is also related to an increase in the amount of methane (Figure 5). This trend is in line with the assumption that the methane is formed by bacterial reduction of carbon dioxide, which is assumed to be the main methane-forming process in the immature stage of an organic source material (Claypool et al., 1974). Such a reduction process would therefore generate isotopically light methane.

In this way the carbon isotope ratios of head space gases from Leg 42B show the bacterial formation of methane and indicate the immature stage of the organic material of these gases. 


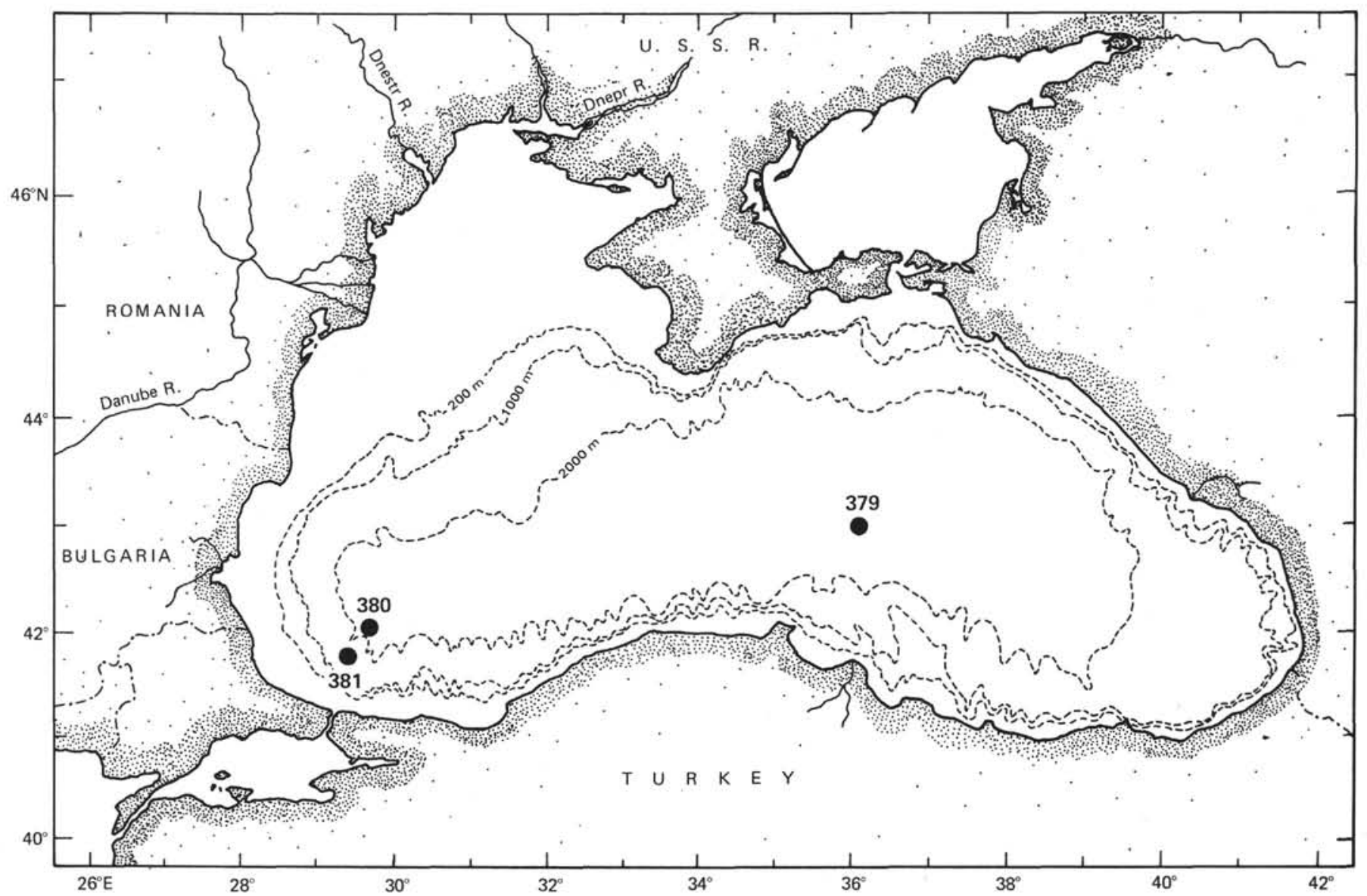

Figure 1. Leg $42 B$ drill sites.

\section{REFERENCES}

Claypool, G.E. and Kaplan, I.R., 1974. The origin and distribution of methane in marine sediments. In Kaplan, I.R. (Ed.), Natural gases in marine sediments: New York (Plenum Press), p. 99-139.
Lebedew, W.C., Owsjannikow, G.A., Moglilewskij, G.A., and Bogdanow, W.M., 1969, Fraktionierung der Kohlenstoffisotope durch mikrobiologische Prozesse in der biochemischen Zone: Zeitschr. Angew. Geolog. v. 15, p. 621624. 
TABLE 1

Head Space Gas Composition (vol \%) and Isotope Ratios $(\%$ ), Standard: PDB (Section: 10 = "Core Catcher"

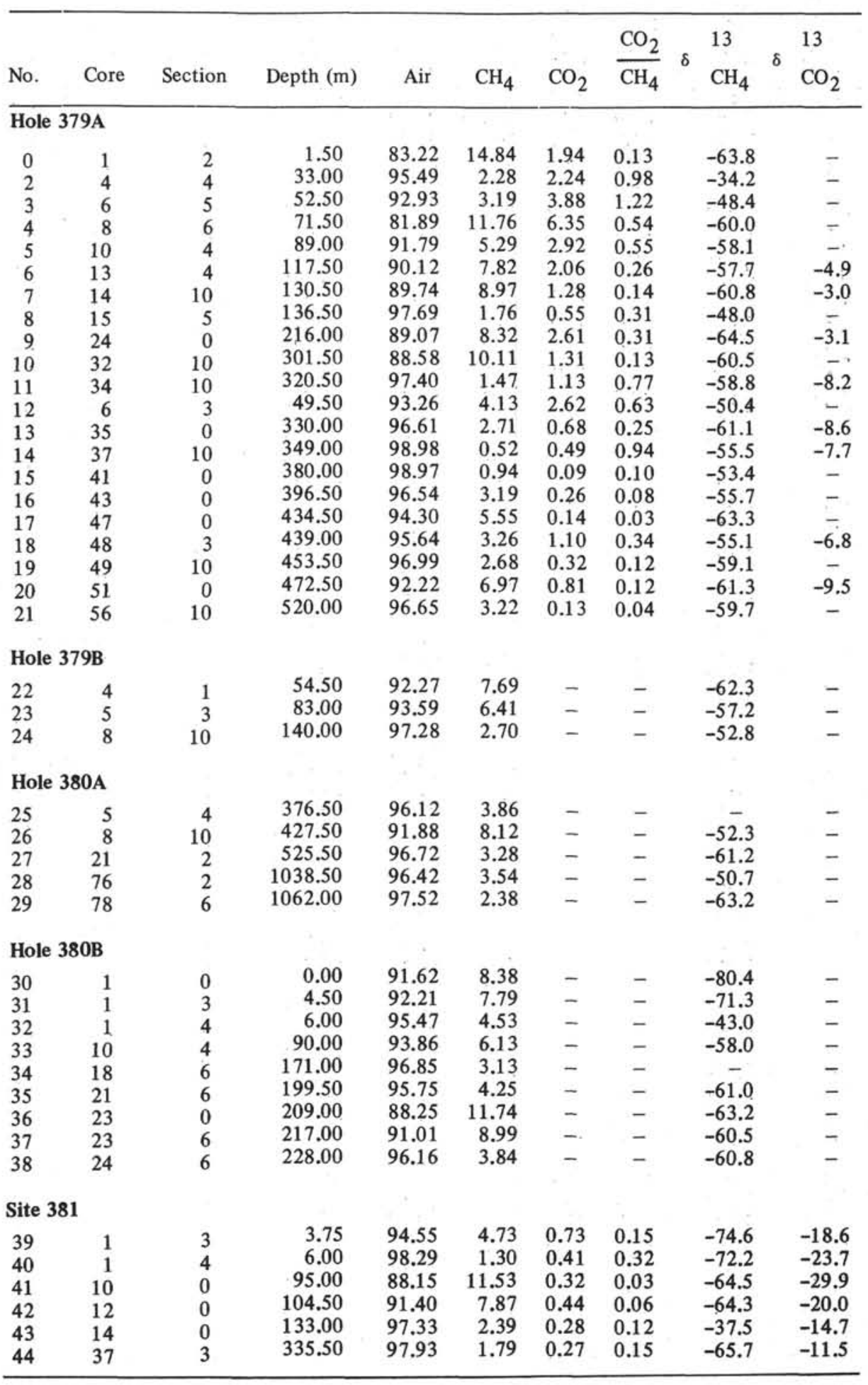


TABLE 2

Hydrocarbon Composition (vol \%) and Ratios of Gas Components

\begin{tabular}{|c|c|c|c|c|c|c|c|c|c|c|}
\hline & & & & & & & . & & $\mathrm{i}-\mathrm{C}_{4} \mathrm{H}_{10}$ & i- $\mathrm{C}_{5} \mathrm{H}_{12}$ \\
\hline No. & Depth (m) & $\mathrm{CH}_{4}$ & $\mathrm{C}_{2} \mathrm{H}_{6}$ & $\mathrm{C}_{3} \mathrm{H}_{8}$ & $\mathrm{i}-\mathrm{C}_{4} \mathrm{H}_{10}$ & $\mathrm{n}-\mathrm{C}_{4} \mathrm{H}_{10}$ & $\mathrm{i}-\mathrm{C}_{5} \mathrm{H}_{12}$ & $\mathrm{n}-\mathrm{C}_{5} \mathrm{H}_{12}$ & $\overline{\mathrm{n}-\mathrm{C}_{4} \mathrm{H}_{10}}$ & $\overline{n-C} \mathrm{C}_{5} \mathrm{H}_{12}$ \\
\hline
\end{tabular}

Hole 379A

$\begin{array}{rrrrrr}0 & 1.50 & - & - & - & - \\ 2 & 33.00 & - & - & - & - \\ 3 & 52.50 & - & - & - & - \\ 4 & 71.50 & - & - & - & - \\ 5 & 89.00 & - & - & - & - \\ 6 & 117.50 & - & - & - & - \\ 7 & 130.50 & - & - & - & - \\ 8 & 136.50 & - & - & - & - \\ 9 & 216.00 & - & - & - & - \\ 10 & 301.50 & - & - & - & - \\ 11 & 320.50 & - & - & - & - \\ 12 & 49.50 & - & - & - & - \\ 13 & 330.00 & - & - & - & - \\ 14 & 349.00 & - & - & - & - \\ 15 & 380.00 & - & - & - & - \\ 16 & 396.50 & - & - & - & - \\ 17 & 434.50 & - & - & - & - \\ 18 & 439.00 & - & - & - & - \\ 19 & 453.50 & - & - & - & - \\ 20 & 472.50 & - & - & - & - \\ 21 & 520.00 & - & - & - & -\end{array}$

Hole 379B

$\begin{array}{rrrrrrrrrrr}22 & 54.50 & 99.53 & 0.20 & 0.12 & 0.06 & 0.09 & - & - & - & - \\ 23 & 83.00 & 99.96 & 0.01 & 0.01 & 0.00 & 0.01 & 0.01 & - & - & - \\ 24 & 140.00 & 98.84 & 0.01 & 0.02 & 0.01 & 0.02 & 0.95 & 0.15 & 0.50 & 6.34\end{array}$

\section{Hole 380A}

$\begin{array}{lr}25 & 376.50 \\ 26 & 427.50 \\ 27 & 525.50 \\ 28 & 1038.50 \\ 29 & 1062.00\end{array}$

$\begin{array}{lll}99.81 & 0.06 & 0.03 \\ 99.95 & 0.03 & 0.01 \\ 99.84 & 0.13 & 0.01 \\ 98.55 & 0.68 & 0.36 \\ 95.84 & 1.14 & 1.44\end{array}$

0.01
0.01
0.02
0.12
0.77

0.01
0.01
-
0.03
0.21

0.03
-
-
0.27
0.60

Hole 380

$\begin{array}{rr}30 & 0.00 \\ 31 & 4.50 \\ 32 & 6.00 \\ 33 & 90.00 \\ 34 & 171.00 \\ 35 & 199.50 \\ 36 & 209.00 \\ 37 & 217.00 \\ 38 & 228.00\end{array}$

$\begin{array}{llll}99.98 & 0.00 & 0.00 & 0.00 \\ 99.99 & 0.00 & 0.00 & 0.00 \\ 99.91 & 0.01 & 0.00 & 0.04 \\ 99.93 & 0.02 & 0.01 & 0.00 \\ 99.54 & 0.01 & 0.03 & 0.10 \\ 99.91 & 0.01 & 0.01 & 0.01 \\ 99.98 & 0.01 & 0.01 & 0.01 \\ 99.98 & 0.00 & 0.01 & 0.00 \\ 99.95 & 0.01 & 0.01 & 0.01\end{array}$

0.01
$-\overline{03}$
0.00
0.07
0.00
0.00
0.00
0.01

0.00
-
0.00
0.02
0.16
0.02
0.00
0.00
0.01

0.00
0.00
-
0.00
0.10
0.04
$-\overline{00}$
0.01

$\begin{array}{cc}0.33 & - \\ - & - \\ - & - \\ 0.67 & 14.00 \\ 1.50 & 1.67 \\ 1.50 & 0.67 \\ -\overline{00} & -\overline{0} \\ 2.00 & 1.00 \\ 0.50 & 1.00\end{array}$

Site 381

\begin{tabular}{|c|c|c|c|c|c|c|c|c|c|c|}
\hline 39 & 3.75 & 99.99 & 0.01 & - & - & - & - & - & - & - \\
\hline 40 & 6.00 & 99.98 & 0.02 & - & - & - & - & - & - & - \\
\hline 41 & 95.00 & 99.99 & 0.01 & - & - & - & - & - & - & - \\
\hline 42 & 104.50 & 99.97 & 0.02 & 0.00 & 0.01 & - & - & - & - & - \\
\hline 43 & 133.00 & 100.00 & 0.00 & - & - & - & - & - & - & - \\
\hline 44 & 335.50 & 99.63 & 0.32 & 0.06 & - & - & - & - & - & - \\
\hline
\end{tabular}



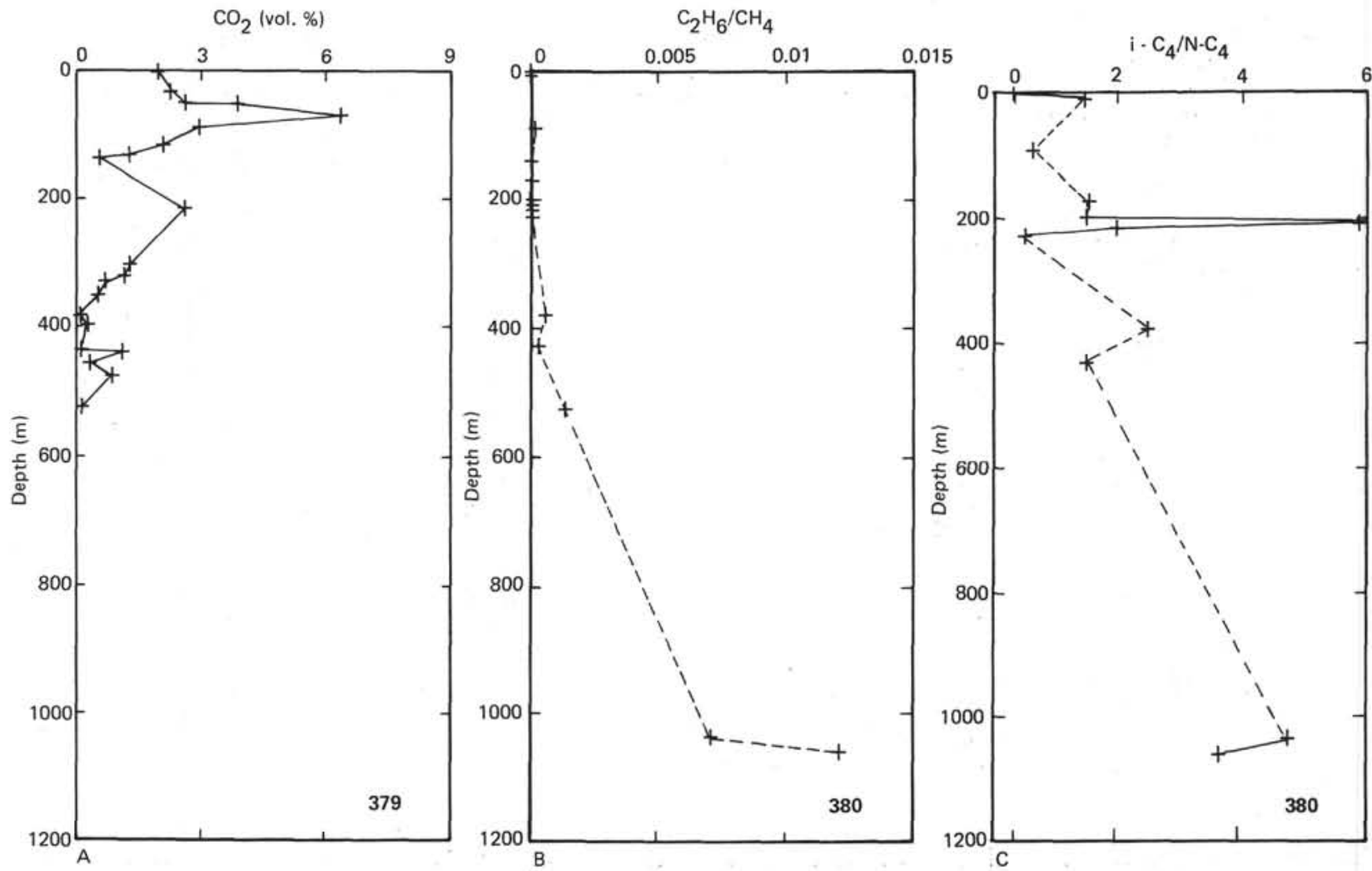

Figure 2. (A) Carbon dioxide content in head space versus depth - Site 379. (B) Ethane/methane ratio versus depth Site 380. (C) i-butane/n-butane ratio versus depth - Site 380.
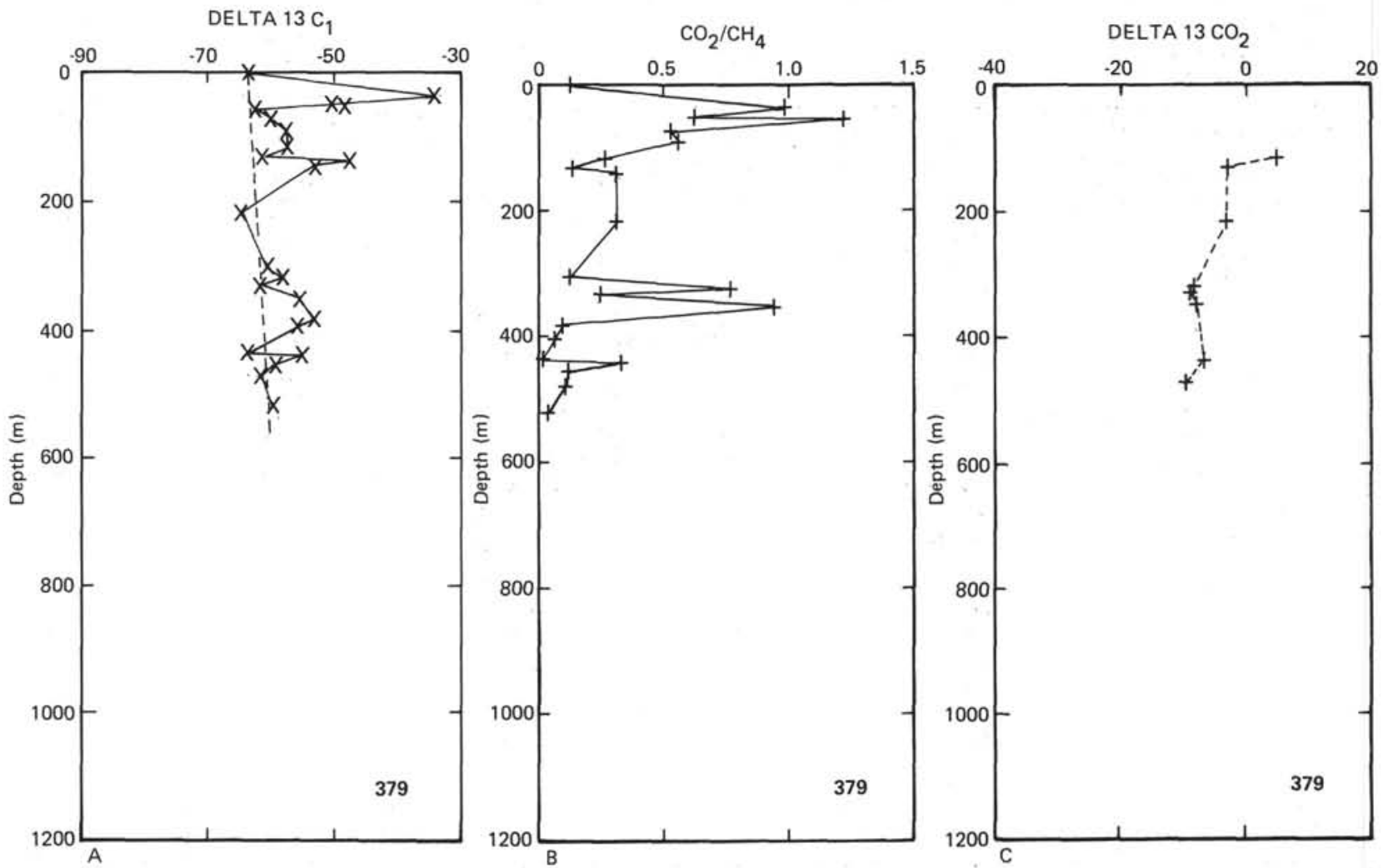

Figure 3. (A) Carbon isotope ratios of methane versus depth-Site 379 (\% PDB). (B) Carbon dioxide/methane ratio versus depth - Site 379. (C) Carbon isotope ratios of carbon dioxide versus depth - Site 379 (\% PDB). 


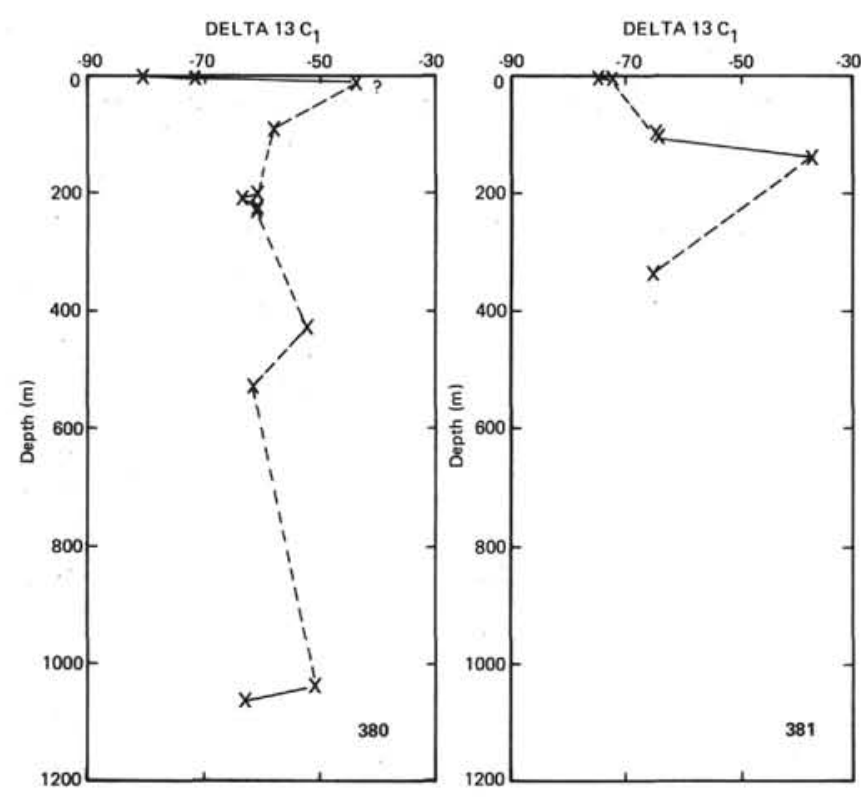

Figure 4. Carbon isotope ratios of methane versus depth Sites 380, 381 (\% PDB).

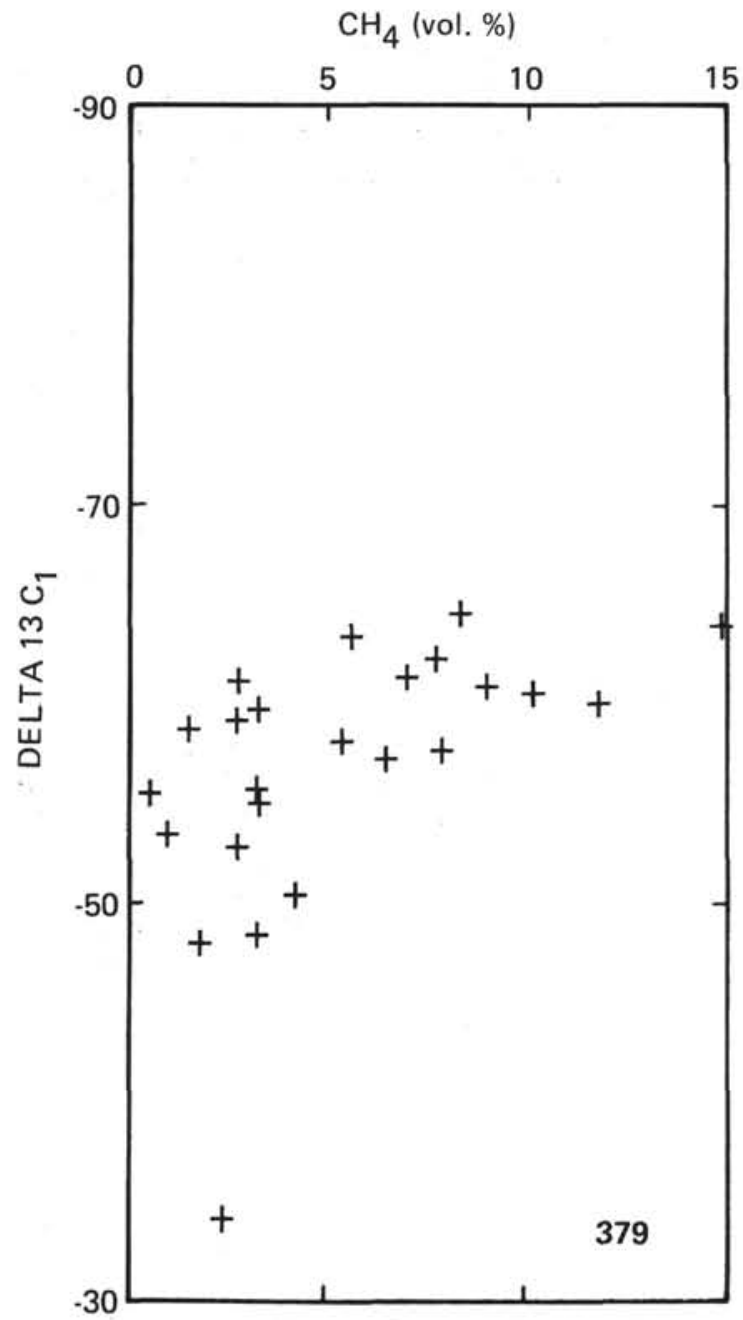

Figure 5. Methane content in head space versus carbon isotope ratios of head space methane. 